\title{
Profil Mesenchymal Stem Cell (MSC) Pasien Klinik Hayandra Pada Media Kultur Bersuplemen Menggunakan Flow Cytometry
}

\author{
Adlia Khalisha ${ }^{1}$, Riris L. Puspitasari ${ }^{1}$, Karina F. Moegni ${ }^{2}$, Imam Rosadi $^{2}$, Iis Rosliana ${ }^{2}$ \\ ${ }^{1}$ Program Studi Biologi (Bioteknologi), Fakultas Sains dan Teknologi, Universitas Al Azhar Indonesia, Jalan \\ Sisingamangaraja, Kompleks asjid Agung Al Azhar, Kebayoran Baru, Jakarta Selatan 12110 \\ ${ }^{2}$ Klinik Hayandra, Yayasan Hayandra Peduli, Jl. Kramat 6 No. 13, Kenari, Senen, Jakarta Pusat.
}

Penulis untuk Korespondensi/E-mail: adlia_grs@yahoo.com

\begin{abstract}
Abstrak - Mesenchymal Stem Cell (MSC) berpotensi untuk digunakan dalam pengobatan karena bersifat multipoten, dapat bermigrasi, dapat berproliferasi. MSC dikultur menggunakan media basal dengan penambahan suplemen, seperti Fetal Bovine Serum (FBS) dan Platelet-Rich Plasma(PRP) untuk mendukung pertumbuhannya. FBS dan PRP memiliki bahan dasar yang berbeda yaitu FBS berasal dari serum fetus sapi sedangkan PRP berasal dari plasma manusia, sehingga perlu dilakukan analisis karakter MSC yang dikultur pada media dengan penambahan FBS atau PRP. Tujuan penelitian adalah untuk menganalisis profil MSC yang dikultur pada media dengan penambahan FBS $10 \%$ atau PRP $10 \%$. Metode yang dilakukan adalah isolasi MSC, pewarnaan MSC, penentuan populasi sel, dan analisis statistik. Penanda yang digunakan berupa CD73, CD90, CD105 dan Lineage negative (CD45/CD34/CD11b/CD19/HLA-DR). Sampel MSC didapatkan dari 8 orang pasien Klinik Hayandra. Hasil dari penelitian menunjukkan bahwa tidak ada perbedaan yang signifikan dari seluruh marker CD, yaitu Lin-(-)/CD90+ $(p=0,16)$, Lin- $(+) / C D 90+(p=0,43)$, dan CD105+/CD73+ $(p=0.5)$. Walaupun tidak memiliki perbedaan nyata, namun PRP cenderung memberikan hasil yang lebih baik daripada FBS, sehingga PRP dapat dijadikan sebagai suplemen alternatif dalam mengkultur MSC.
\end{abstract}

Abstract - Mesenchymal Stem Cell (MSC) were used in many therapy in curing degenerative diseases. Because of its multipotent character, MSC could migrated, proliferated, and differentiated. In culture, MSC needed some suplements such as Fetal Bovine Serum (FBS) and Platelet-Rich Plasma (PRP) to support the growth. FBS and PRP had different ingredients based on their resources. FBS is derived from bovine fetus serum whereas PRP comes from human plasma, so became necessary to analyze MSC characters cultured in media with FBS or PRP suplements. The purpose of research was to analyze the MSC profile cultured with addition of $10 \%$ FBS and $10 \%$ PRP. The methodology were MSC isolation, MSC staining, cell population determination, and statistic analysis. The markers used are CD73, CD90, CD105 and Lineage negative (CD45 / CD34 / CD11b / CD19 / HLA-DR). Samples were obtained from 8 patients of Hayandra Clinic. The results of research showed that there were no significantly differences from all CD markers. Lin - (-) / CD90 + (p = 0.16), Lin - (+) / CD90 + (p= 0.43), and CD105 + / CD73 + $(p=0.5)$ gave different character in FBS or PRP suplementation. Although no significant difference, PRP tends to give better results than FBS in culturing MSC. This finding informed that PRP could be used as an alternative suplement in culturing MSC.

Keywords - Mesenchymal Stem Cell (MSC), Fetal Bovine Serum (FBS), Platelet-Rich Plasma (PRP) 


\section{PENDAHULUAN}

\section{Latar Belakang}

Mesenchymal Stem Cell (MSC) berpotensi untuk digunakan dalam pengobatan karena memiliki sifat multipoten, dapat bermigrasi, berproliferasi, dan berdiferensiasi [1]. Berbagai sifat MSC tersebut digunakan sebagai terapi penggantian dan penyembuhan jaringan yang rusak. MSC dapat berdiferensiasi menjadi jaringan mesenkim seperti tulang, kartilago, otot, ligamen, tendon dan adiposa. MSC dapat diidentifikasi berdasarkan Cluster of Differentiation (CD) seperti CD105, CD73 dan CD90 menggunakan alat flow cytometry. Karakterisasi MSC perlu dilakukan sebelum digunakan utuk penelitian lebih lanjut, seperti uji proliferasi, ekspresi gen dan homogenitas MSC itu sendiri [2].

MSC ditumbuhkan dan diperbanyak pada media basal dengan penambahan suplemen, seperti Fetal Bovine Serum (FBS) untuk mendukung proses pertumbuhannya. FBS memiliki kandungan antara lain asam amino, protein, vitamin larut lemak, karbohidrat, lipid, hormon, dan faktor pertumbuhan. Berbagai penelitian telah dilakukan untuk mengkultur MSC dengan jenis suplemen media yang lain yaitu Platelet Rich Plasma (PRP). Penggunaan PRP dilakukan sebagai alternatif dari FBS karena PRP berasal dari manusia sehingga dapat mengeliminasi bahaya dari FBS yang xenogenik. Plasma mengandung faktor pertumbuhan, fibrinogen, glukosa, lemak, nitrogen, enzim, hormon, vitamin, dan pigmen mampu mendukung proliferasi sel punca dari lipoaspirat [3]. Adanya perbedaan kandungan FBS dan PRP memungkinkan karakter MSC yang dihasilkan berbeda. Penentuan karakter MSC dapat dilakukan dengan menggunakan alat flow cytometry.

Penelitian sebelumnya yang dilakukan oleh [4] telah membandingkan MSC yang dikultur dalam media dengan penambahan FBS dan PRP, hanya menggunakan salah satu penanda yang ditentukan International Society for Cellular Therapy (ISCT) dari MSC, yaitu CD 90, serta penanda tambahan berupa CD29 menggunakan flow cytometry [5]. Hasil dari penelitian tersebut menyatakan bahwa ekspresi CD90 dengan PRP memiliki nilai yang lebih tinggi dibandingkan menggunakan FBS. Pada kegiatan penelitian ini MSC yang dikultur dalam media dengan FBS atau PRP dianalisis menggunakan penanda standar yang ditentukan oleh ISCT untuk karakterisasi MSC yaitu CD73, CD90, CD105, dan Lineage-Negative
(CD45/CD34/CD11b/CD19/ DLA-DR PE).

Sehingga penelitian ini diharapkan dapat melengkapi data dari penelitian yang dilakukan oleh [4].

\section{Tujuan dan Manfaat}

Penelitian ini dilakukan untuk membandingkan profil MSC yang dikultur pada media dengan penambahan FBS atau PRP. Manfaat penelitian adalah diperolehnya informasi mengenai perbandingan profil MSC yang dikultur pada media dengan penambahan FBS atau PRP.

\section{TINJAUAN PUSTAKA}

\section{Mesenchymal Stem Cell (MSC)}

Mesenchymal Stem Cell (MSC) merupakan sel stromal non-hematopoetik yang berada di stroma sumsum tulang belakang maupun stroma organ lain. MSC memiliki proses regulasi yang tinggi pada proliferasi, migrasi, diferensiasi, dan maturasi. MSC dapat berdiferensiasi menjadi dan berkontribusi dalam regenerasi jaringan mesenkim seperti tulang, kartilago, otot, ligamen, tendon, dan adiposa. Sifat multipotensi dan migrasi dari MSC kemudian dipelajari lebih lanjut karena memiliki potensial dalam penyembuhan regeneratif. MSC dapat diisolasi dari berbagai jaringan seperti sumsum tulang belakang, jaringan adiposa, dermis, hati, dan folikel rambut. Penelitian yang dilakukan dalam penyembuhan menggunakan MSC menghasilkan hasil yang baik untuk kasus seperti kelainan Crohn, osteogenesis imperfect, kerusakan kartilago dan serangan jantung. Kemampuan MSC dalam memperbaiki beberapa kasus penyakit dan kelainan membuat banyak peneliti yang mempelajari MSC secara lebih lanjut, seperti penelitian lanjut mengenai hubungan penanda MSC dengan sel dewasa [2].

Lembaga ISCT (International Society for Cellular Therapy) menetapkan standar kriteria untuk mengidentifikasi MSC manusia untuk kepentingan studi kesehatan. Tiga kriteria MSC tersebut adalah menempel pada wadah kultur, mengekspresikan CD73, CD90 dan CD105, dan memiliki diferensiasi multipotensi. MSC dapat berdiferensiasi menjadi osteoblast, kondroblast, dan adiposa. Sebanyak $\geq 95 \%$ populasi MSC mampu mengekspresikan CD105, CD73 dan CD90 akan tetapi tidak mengekspresikan CD45, CD34, CD14 atau CD11b, CD79 $\alpha$ atau CD19 dan HLA kelas II yang merupakan penanda hematopoetik, melalui flow cytometry. Ekspresi permukaan MSC seperti di atas 
merupakan kriteria umum untuk identifikasi MSC [6].

\section{Media Kultur MSC \\ Kultur MSC dilakukan menggunakan media sintesis yang terdiri dari basal medium (medium dasar) dan suplemen. Medium dasar diformulasikan dengan berbagai senyawa kimia yang mendukung kondisi kultur seperti larutan penyangga dan berbagai mineral. Suplemen yang digunakan untuk kultur MSC pada umumnya adalah Fetal Bovine Serum (FBS) dan Platelet-Rich Plasma (PRP) [7].}

FBS merupakan suplemen media yang umum digunakan untuk kultur sel. FBS memberikan stimulasi pertumbuhan sel yang berasal dari biokimia yang berasiasi dengan darah yang bertanggung jawab terhadap perkembangan seluler pada pendewasaan fetus. Penggunaan FBS dapat diaplikasikan pada semua sel mamalia yang ditumbuhkan secara in vitro. FBS didapatkan dari darah fetus sapi sehat (sehat yang dapat dikonsumsi manusia). Darah yang diambil kemudian diproses dan dilakukan berbagai uji seperti uji kesterilan dengan iradiasi gamma maupun pemanasan untuk inaktivasi [8]. Beberapa kandungan dari FBS adalah asam amino, gula, lipid, dan hormon [9]. FBS telah diuji untuk kultur MSC sehingga memberikan hasil yang mendukung untuk pertumbuhan MSC dan mempertahankan multipotensi [4].

PRP merupakan produk dari darah dengan konsentrasi trombosit yang tinggi, dan berasal dari plasma manusia yang mengandung sejumlah faktor pertumbuhan. Faktor pertumbuhan pada PRP yang dilepaskan melalui degranulasi akan menstimulasi pemulihan dari berbagai jaringan dan jika diaplikasikan pada luka PRP mempercepat regenerasi sel [10]. Penggunaan PRP telah dilaporkan dapat menstimulasi perbaikan jaringan muskoskeletal seperti otot, tulang, kulit, tendon, dan kartilago. Selain kemampuannya mempengaruhi proliferasi sel, PRP juga dapat menstimulasi migrasi dan diferensiasi sel, seperti migrasi pada sel progenitor subkondral dan diferensiasi kondrogenik stem cell. Kemampuan PRP dalam mempengaruhi proliferasi, migrasi, dan diferensiasi sel menyebabkan PRP banyak digunakan sebagai alternatif suplemen FBS pada aplikasi medis maupun kultur sel [11].

Terdapat dua jenis kit flow cytometry, yaitu multicolor dan singlecolor. flow cytometry multicolor digunakan untuk mengidentifikasi MSC, yang menunjukkan presentase heterogenitas sel dalam populasi dengan berbagai ekspresi penanda khusus MSC. Sedangkan flow cytometry single color hanya dapat menunjukkan presentase sel yang diekspresikan pada setiap penanda MSC secara individu [14].

\section{METODE PENELITIAN}

\section{Waktu dan Tempat Pelaksanaan}

Kegiatan penelitian ini dilaksanakan pada bulan Februari 2018 sampai Maret 2018 dan bertempat di Klinik Hayandra, Jakarta Pusat.

\section{Metode Penelitian}

Sampel penelitian adalah MSC dari 8 orang pasien Klinik Hayandra .

1. Persiapan sampel MSC pasien sebelum karakterisasi

Karakterisasi MSC dilakukan menggunakan flow cytometry dan menggunakan penanda berlabel senyawa fluoresens. Marker yang digunakan yaitu CD73, CD 90, dan CD105 (positif > 95\%) dan tidak mengekspresikan marker CD45, CD34, CD14 atau CD11b, CD79a dan HLA-DR (positif < 2\%) yang merupakan penanda sel hematopoetik [12].

\section{Karakterisasi MSC dengan Flow cytometry}

Isotipe dan sampel masing-masing ditambahkan dengan pewarna kit BD Human MSC Stemflow ${ }^{\mathrm{TM}}$, yaitu CD90-FITC-a, CD105 PerCP-Cy5.5, CD73APC, dan Lin Negative PE-A (CD45/CD34/CD11b/CD19/DLA-DR PE) untuk sampel dan CD90-FitC Mouse Anti-Human, CD105 PerCP-Cy5.5 Mouse Anti-Human, CD73 APC Mouse Anti-Human untuk isotype masing-masing 2 $\mu l$ dan divortex. Seluruh tabung diinkubasi selama 30 menit dengan suhu $4^{\circ} \mathrm{C}$. Setelah itu tabung sampel dan isotipe ditambahkan dengan running buffer sebanyak $1 \mathrm{ml}$ kemudian di vortex dan disentrifugasi. Supernatan dibuang kemudian tabung sampel dan isotipe masing-masing ditambahkan dengan $100 \mu \mathrm{l}$ larutan penyangga. Tabung sampel, isotipe, dan kontrol dianalisa dengan flow cytometry.

\section{Penentuan Populasi sel}

Penentuan populasi sel dilakukan dengan penggunaan kontrol isotipe, agar dapat memastikan pewarnaan pada sampel merupakan hasil ikatan dengan antibodi yang spesifik. Pembatasan ini akan mengungkapkan ikatan antibodi atau fluorophore non-spesifik lainnya. Gating atau pembatasan 
dilakukan dengan memberi batas populasi terhadap ekspresi CD pada sampel pasien.

Terdapat dua kontrol untuk gating pada flow cytometry yaitu unstained dan isotipe. Kontrol unstained berfungsi untuk menentukan latar belakang fluorescence maupun autofluorescence seperti monosit/makrofag, sel kultur, atau sel teraktivasi sehingga dapat menentukan populasi sel yang negatif. Kontrol isotipe merupakan kontrol yang menggunakan antibodi yang sama dengan antibodi sampel yang diujikan tetapi tidak terdapat pada sampel yang dianalisis, biasanya berasal dari spesies lain seperti tikus. Kontrol isotipe dapat menentukan ikatan non-spesifik antibodi fluoresens [15]. Pembatasan setiap CD pada kontrol unstained maupun isotipe tidak lebih dari $2 \%$ untuk batas positifnya, menghindari adanya stem cell hematopoetik [16]. Hasil gating ditunjukkan dalam grafik dot plots dan histogram (Gambar 1).
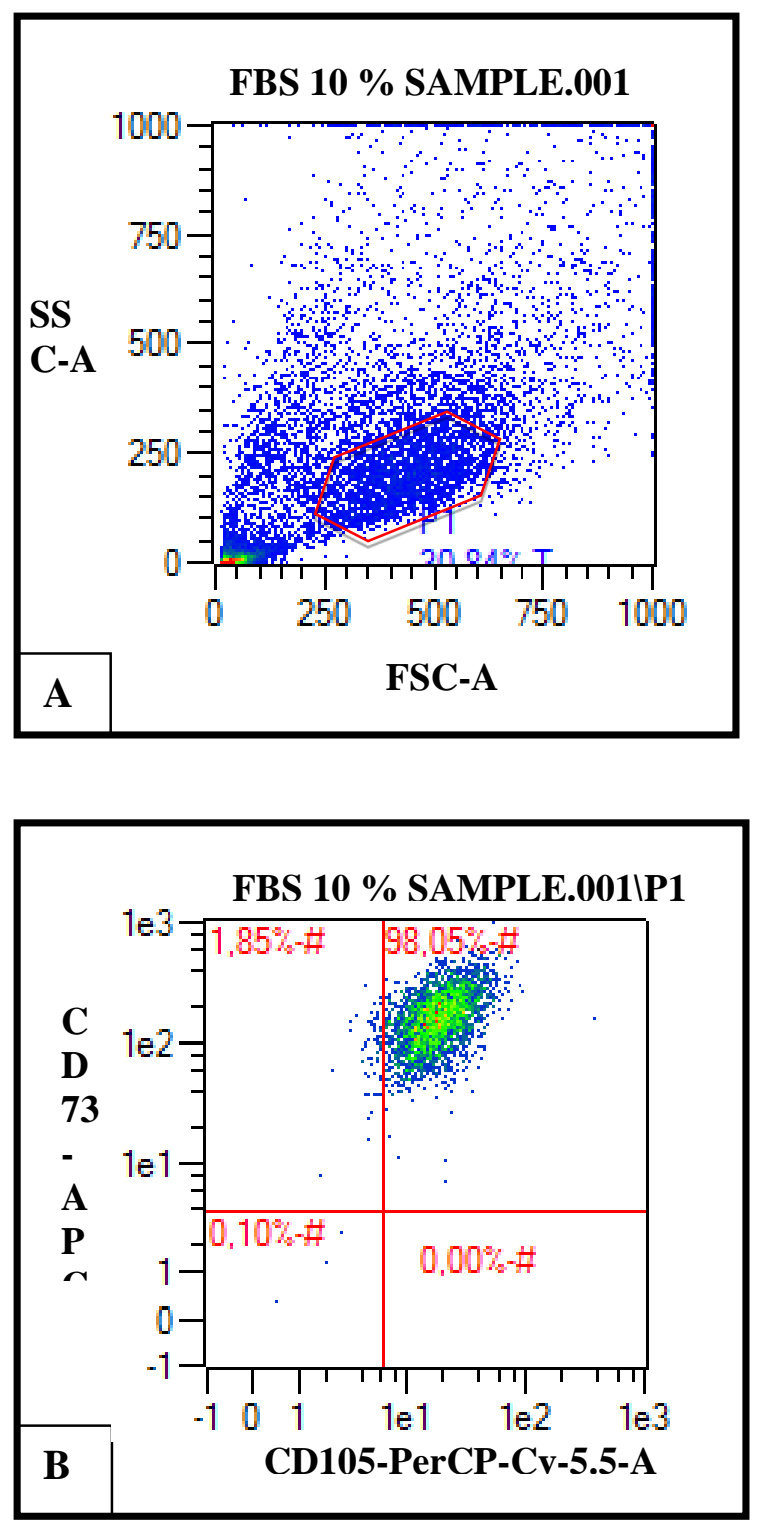
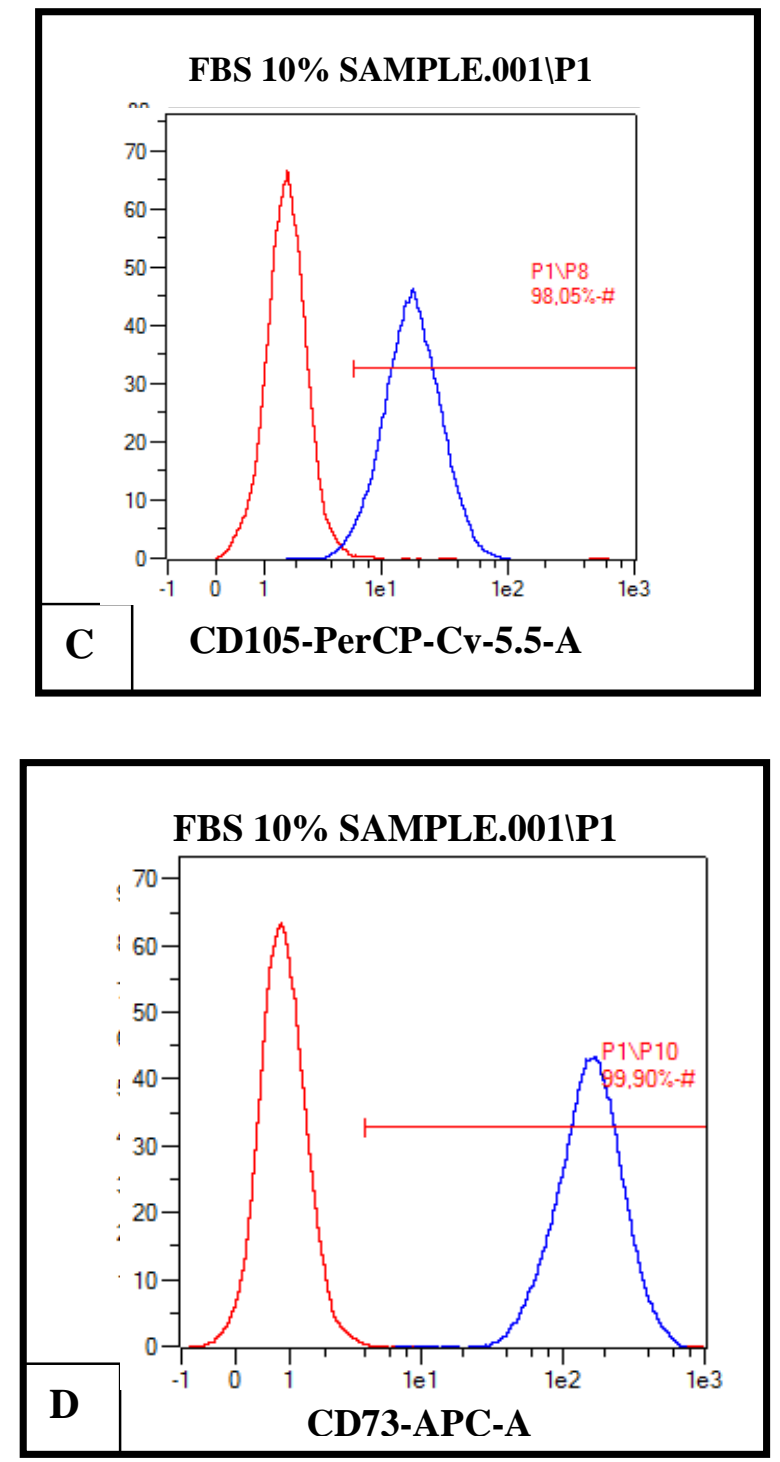

Gambar 1 Penentuan populasi data profil MSC untuk penanda CD105 dan CD73. A) Populasi keseluruhan sel,

B) Populasi sel hasil gating CD105 dan CD73, C) Gating CD105, D) Gating CD73

(Sumber : Dokumen pribadi, 2018)

Tahap pertama dalam melakukan gating adalah membuka data hasil alat flow cytometry yang terhubung dengan software MACSQuantify pada laptop. Data sel MSC yang diterima berupa sebaran keseluruhan sel (Gambar 1 A) yang dapat dipilih populasi terpadat dan ditandai dengan warna merah. Pemilihan populasi dilakukan dengan cara memilih sel yang berkumpul padat dan tidak mengambil bagian pojok kiri bawah yang kemungkinan merupakan debris sel. Tahap kedua ialah membuka histogram kontrol unstained dan kontrol isotipe. Grafik histogram (berwarna merah) diberi batas sebesar $2 \%$ atau kurang untuk memberi batas negatif pada sampel. Setelah itu histogram sampel dibuka dan akan menghasilkan grafik histogram kedua pada panel yang sama (grafik biru), sehingga terlihat 
ekspresi sel pada sampel untuk setiap CD (Gambar $1 \mathrm{C}$ dan D). Hasil perbandingan grafik kontrol dengan sampel ditampilkan dalam bentuk dot plots populasi sel yang menunjukkan posisi besarnya ekspresi sel terhadap CD (Gambar 1 B).

\section{Pengolahan Data}

Pengolahan data dimulai dengan melakukan uji normal dan homogen $(p>0.05)$ untuk menentukan jenis data parametrik dan non parametrik, kemudian dilakukan uji T untuk data parametrik dan uji MannWhitney untuk data non-parametrik $(p<0.05)$ [17].

\section{HASIL DAN PEMBAHASAN}

Data hasil flow cytometry menunjukkan nilai dari ekspresi CD pada MSC. Profil MSC yang dilihat adalah ekspresi dari CD73, CD90, CD105, dan Lineage negative yang terdiri dari marker $\mathrm{CD}$ untuk hematopoetik (CD45/CD34/CD11b/ CD19/HLADR). Marker CD73 juga diekspresikan pada sel T, sel B, stem cell, sel endotel dan sel epitel. Marker CD90 yang berfungsi sebagai adhesi sel, selain diekspresikan oleh stem cell juga terekspresi pada sel endotel dan fibroblas. Berdasarkan penelitian oleh [1] ekspresi CD90 pada spermatogonial stem cell (SSC), hair follicle stem cells (HFSC), dan granulosa cells (GC), memiliki peran dalam pertumbuhan stem cell dan diferensiasinya [18]. Marker CD105 berkaitan dengan proliferasi, diferensiasi dan migrasi sel. CD105 juga memiliki peran dalam melakukan diferensiasi sel adiposit, osteosit, kondrosit dan diekspresikan pada stem cell, monosit, dan sel endotel [19].

Karakterisasi MSC berdasarkan persentase dari penanda positif CD73, CD90, CD105, dan penanda negatif Lineage negative (Lin-) yang telah ditetapkan oleh lembaga ISCT (Internatioal Society for Cellular Therapy). Tabel 1 menunjukkan semakin tinggi persentase penanda positif maka semakin baik [6].

Tabel 1. Perbandingan profil MSC antara media FBS dan PRP

\begin{tabular}{cccc}
\hline $\begin{array}{c}\text { Marker } \\
\text { Media }\end{array}$ & $\begin{array}{c}\text { Lin-(-) } \\
\text { /CD90+ }\end{array}$ & $\begin{array}{c}\text { Lin-(+) } \\
\text { /CD90+ }\end{array}$ & $\begin{array}{c}\text { CD105+ } \\
\text { /CD73+ }\end{array}$ \\
\hline $\begin{array}{r}\text { FBS } \\
(\mathbf{n}=\mathbf{6})\end{array}$ & $97,05 \%$ & $0,95 \%$ & $78,02 \%$ \\
$\mathbf{P R P}$ & $99,54 \%$ & $0,33 \%$ & $57,25 \%$ \\
$(\mathbf{n = 2})$ & & & \\
$\mathbf{p}$ & 0,16 & 0,43 & 0,5 \\
\hline
\end{tabular}

Berdasarkan tabel hasil perbandingan profil MSC antara media dengan penambahan FBS atau PRP, CD (Lin-(-) /CD90+, Lin-(+) /CD90+, CD105+ /CD73+) tidak memiliki perbedaan nyata. Lin-(-) /CD90+ menunjukkan tingkat ekspresi CD90 pada MSC sehingga hasil kultur dengan persentase tertinggi adalah yang paling baik. Variabel Lin-(+) /CD90+ menunjukkan kemurnian karena Lin- yang positif merupakan tanda adanya profil MSC dengan sifat hematopoetik, sehingga semakin kecil presentase hasil kultur. Sedangkan CD105+ /CD73+ menunjukkan tingkat proliferasi, diferensiasi dan migrasi sel oleh CD105 dan positif CD73, sehingga persentase tertinggi adalah yang paling baik. Walaupun tidak memiliki perbedaan nyata, Lin-(-) /CD90+ $(\mathrm{p}=0,16)$ memiliki nilai terbaik pada media dengan penambahan PRP, begitu pula dengan Lin$(+) / C D 90+(\mathrm{p}=0,43)$ yang memiliki nilai terbaik pada PRP. Akan tetapi terdapat perbedaan antara CD105+ /CD73+ dari hasil sebelumnya, yaitu memiliki nilai yang lebih baik ada FBS. Berdasarkan hasil keseluruhan, PRP memperlihatkan hasil yang lebih baik dibandingkan dengan FBS [6].

MSC secara fenotip ditetapkan dengan kehadiran penanda pada permukaan sel CD73, CD90, dan CD105 sebagai penanda positif yang harus lebih besar atau sama dengan $95 \% \quad(\geq 95 \%)$, dan ketidakhadiran penanda yang masuk dalam Linyang harus dibawah atau sama dengan $2 \%(\leq 2 \%)$ [16]. Berdasarkan data dari Tabel 1, karakter fenotip MSC media PRP lebih baik dibandingkan dengan media FBS dengan nilai variabel Lin-(-) /CD90+ (98,64\%), dan nilai CD105+/CD73+ (68,99\%) yang lebih tinggi dan nilai Lin-(+)/CD90+ yang lebih rendah $(0,65 \%)$, dari pada nilai dengan media FBS. Nilai Lin-(-) /CD90+ (99,54 \%) media PRP lebih tinggi dari media FBS, nilai Lin-(+) /CD90+ $(0,33 \%)$ media PRP lebih rendah dari media FBS. Nilai CD105+ /CD73+ (78,02\%) pada media FBS lebih tinggi dari media PRP. Berdasarkan hasil tersebut, kultur MSC suplemen PRP lebih baik dibandingkan FBS. Walaupun variabel CD105+ /CD73+ lebih tinggi pada FBS namun homogenitas sel didapatkan jauh lebih tinggi dari PRP dan hasil tidak menunjukkan perbedaan yang nyata $(\mathrm{p}>0.05)$. Jika dilihat dari ketentuan yang diutarakan ISCT dalam [20], maka MSC yang didapatkan yang dikultur dalam media mengandung FBS maupun PRP masih belum memenuhi syarat MSC murni. Hal ini disebabkan oleh presentase variabel CD105+/CD73+, yang merupakan penanda positif, tidak diekspresikan lebih dari 95\% [16]. 
Medium untuk kultur stem cell membutuhkan komponen penting seperti faktor untuk mendukung pertumbuhan sel. Faktor pertumbuhan bisa didapatkan baik dari jenis media, seperti conditioned medium (CM), maupun dari penambahan suplemen seperti FBS dan PRP [21]. Serum digunakan sebagai penyedia asam amino, protein, vitamin larut lemak, karbohidrat, lipid, hormon, dan faktor pertumbuhan. Serum juga memiliki fungsi buffer untuk media kultur, menginaktifasi enzim proteolitik, meningkatkan viskositas medium, dan mengkondisikan permukaan pertumbuhan dari kultur pembuluh [22]. Sedangkan PRP memiliki kandungan umum dari plasma seperti faktor pertumbuhan, fibrinogen, substansi non-protein, glukosa, lemak, nitrogen, enzim, hormon, dan vitamin [23].

Perbedaan yang paling terlihat berdasarkan komposisi antara FBS dan PRP adalah PRP memiliki trombosit (platelet) sementara FBS tidak. Trombosit memiliki banyak faktor pertumbuhan yang dapat meningkatkan ekspresi penanda MSC pada hasil kultur [20]. PRP harus diaktivasi menggunakan $\mathrm{CaCl} 2$ untuk memecahkan trombosit, sehingga faktor pertumbuhan akan disekresikan trombosit. Sekresi faktor pertumbuhan tersebut dapat digunakan oleh sel untuk proliferasi, migrasi dan atau diferensiasi. Beberapa faktor pertumbuhan yang ditemukan pada FBS antara lain insulin-like growth factor (IGF-1), transforming growth factor$\beta 1$ (TGF- $\beta 1$ ), dan fibroblast growth factor (FGF-2) [24]. Penelitian yang dilakukan oleh [24], menunjukkan bahwa berbagai faktor pertumbuhan seperti platelet derived growth factor (PDGF-AB), epidermal growth factor (EGF), basic fibroblast growth factor (bFGF), hepatocyte growth factor (HGF), transforming growth factor- $\beta 1$ (TGF- $\beta 1$ ) dan vascular endothelial growth factor (VEGF) yang terkandung dalam PRP memiliki konsentrasi lebih tinggi dibanding FBS [25].

Hal serupa juga ditemukan pada hasil penelitian ini yaitu PRP memberikan hasil lebih baik dari FBS untuk mendukung kultur MSC. Dengan demikian PRP dapat dijadikan sebagai alternatif dari FBS. Sama halnya dengan Embryonic Stem Cell (ESC) yang mampu berdiferensiasi menjadi berbagai tipe sel seperti neuron [26], cardiomyocyte [27], ataupun sel $\beta$ pankreas [28], MSC yang dikultur dengan penambahan PRP juga dapat berdiferensiasi menjadi tipe sel yang diinginkan.

\section{KESIMPULAN DAN SARAN}

\section{Kesimpulan}

1. Perbandingan profil MSC pada media dengan penambahan FBS ataupun PRP tidak berbeda nyata untuk nilai Lin-(-)/CD90+, Lin(+)/CD90+, dan CD105+/CD73+ .

2. Profil MSC menggunakan media dengan PRP memiliki nilai Lin-(-)/CD90+ (99.54\%) dan Lin-(+)/CD90+ (0.33 \%) yang lebih baik dibandingkan menggunakan media dengan FBS.

3. PRP dapat dijadikan sebagai suplemen alternatif dalam mengkultur MSC.

\section{Saran}

Perlu dilakukan penelitian lebih lanjut mengenai pemetaan profil MSC dengan penanda diferensiasi sel. Selain itu perlu dilakukan percobaan kontrol (media bebas suplemen) untuk lebih dapat melihat perbedaan hasil kultur MSC dengan PRP dan FBS.

\section{UCAPAN TERIMAKASIH}

Penulis mengucapkan terima kasih kepada Klinik Hayandra beserta staf dalam menyediakan sarana penelitian dan segala bentuk bimbingan serta arahan, ibu Riris Lindiawati Puspitasari, S.Si., M.Si., atas bimbingannya dalam pembuatan tulisan ilmiah ini.

\section{DAFTAR PUSTAKA}

[1] M. Maleki, F. Ghanbarvand, M. R. Behvarz, M. Ejtemaei and d. e. Ghadirkhomi, "Comparison of Mesenchymal Stem Cell Markers in Multiple Human Adult Stem Cells," International Journal of Stem Cell, vol. 07, no. 02, pp. 118-126, 2014.

[2] R. Puspitasari, "Diferensiasi Embryonic Stem Cells Mencit menjadi Neuron Menggunakan Conditioned Medium [Thesis]," Sekolah Pasca Sarjana, Institut Pertanian Bogor, Bogor, 2009.

[3] R. Ramezanifard, M. Kabiri and H. H. Ahvaz, "Effects of platelet rich plasma and chondrocyte co-culture on MSC chondrogenesis, hypertrophy and pathological responses.," EXCLIJ, vol. 16, pp. 1031-1045, 2017. 
[4] S. Tavakolinejad, M. Khosravi, B. Mashkani, A. E. Bideskan, N. S. Mossavi, P. MR and H. A. D, "The effect of human platelet-rich plasma on adipose-derived stem cell proliferation and osteogenic differentiation.," Journal Iran Biomed, vol. 18, no. 3, pp. 151157, 2014.

[5] Thermo Fisher Scientific, "Growth Factors in Thermo Scienti9c HyClone," 2007. [Online].Available:http://www.stemcell.so/im ages/upload/pdf/528ed1a462859.pdf.

[Diakses pada 3 Maret 2018].

[6] M. Dominici, K. L. Blanc, I. Mueller, I. Slaper-Cortenbanch, F. Marini, D. Krause, R. Deans, A. Keating, D. Prokop and E. Horwitz, "Minimal criteria for defining multipotent mesenchymal stromal cells. The International Society for Cellular Therapy position statement.," Cytotherapy, vol. 8, no. 4, pp. 315-317, 2006.

[7] F. Amini, F. Abiri, T. S. Ramasamy and E. S. S. Tan, "Efficacy of platelet rich plasma (PRP) on skin rejuvenation: A systematic review," Iranian Journal of Dermatology, vol. 18, no. 3, pp. 119-127, 2015.

[8] F. W. Ganong, Buku Ajar Fisiologi Kedokteran ed. 20, Jakarta : EGC, 2003.

[9] Biological Industries, "Introduction to Fetal Bovine Serum Class," Biological Industries, 2017. [Online]. Available: https://www.bioind.com/worldwide/support/te ch-tips-posters/introduction-to-fetalbovineserum-class/. [Diakses pada 14 Maret 2018].

[10] D. Rosenstrauch, G. Poglajen, N. Zidar and I. D. Gregoric, "Stem Cell Therapy for Ischemic Heart Failure," Texas Heart Institute Journal, vol. 32, no. 3, pp. 339-347, 2005.

[11] W. Siegel and L. Foster, "Fetal Bovine Serum: The Impact of Geography," Journal BioProcessing, vol. 12, no. 3, pp. 28-30, 2013.

[12] American Type Culture Collection (ATCC), "ATCC Animal Cell Culture Guide Tips and Techniques for Continuous Cell Lines," 2014. [Online]. Available: https://www.atcc.org/ /media/PDFs/Culture \%20Guides/AnimCellCulture_Guide.ashx. [Diakses pada 15 Maret 2018].

[13] M. Johnson, "Fetal Bovine Serum," Labome, The World of Laboratory, 22 Maret 2012.[Online].

Available: https://www.labome.com/method/F
etal-Bovine-Serum.html. [Diakses pada 26 Mei 2018].

[14] R. Robinson and S. Pellenz, "What is Flow Cytometry (FACS analysis)," antibodiesonline network, 12 Juni 2013. [Online]. Available: https://www.antibodiesonline.com/ resources/17/1247/whatisflowcytometry-facsanalysis/. [Diakses pada 24 April 2018].

[15] R. Azpeitia and A. I, "Partnership between platelet-rich plasma and mesenchymal stem cells: in vitro experience.," Journal Muscles Ligaments Tendons, vol. 4, no. 1, pp. 52-62, 2014.

[16] V. Gonzales, E. d. Mulder, T. d. Boer, G. Hannink, T. v. Tienen, W. v. Heerde and P. Burma, "Platelet-rich plasma can replace fetal bovine serum in human meniscus cell cultures.," Tissue Engineering Part $C$ : Methods, vol. 19, no. 11, 2013.

[17] D. Suryani, J. A, Pawitan, J. Lilianty, R. Y. Purwoko, I. K. Liem and L. Damayanti, "Comparison of fetal bovine serum and platelet-rich plasma on human lipoaspiratederived mesenchymal stem cell proliferation," Medical Journal of Indonesia, vol. 22, no. 3, pp. 146-151, 2013.

[18] J. Martin, M. Gottliebl and C. T. Carson, "Multiparameter Flow Cytometric Analysis," BD Biosciences, USA, 2010.

[19] M. Rahman, Introduction to Flow Cytometry, Oxfor: Serotec Ltd, 2006.

[20] S. D. Sandhaanam, G. Pathalam, S. Dorairaj and V. Savariar, "Mesenchymal stem cells (MSC): Identification, Proliferation and Differentiation," PeerJPrePrints, vol. 1, 2013.

[21] L. Kent, "Cell Culture Basics: Stem Cell Media - The "What" and "Why"," Biological Industries, 1 Juni 2016. [Online]. Available: https://blog.bioind.com/cell-culturebasicsstem-cell-media-the-what-and-why/. [Diakses pada 28 Maret 2018].

[22] C. Rauch, E. Feifel, E. Amann, H. Spotl, H. Schennach, W. Pfaller and G. Gstraunthaler, "Alternatives to the use of fetal bovine serum: human platelet lysates as a serum substitute in cell culture media.," Altex, vol. 28, no. 4, pp. 305-316, 2011.

[23] S. Gurka, A. Hutloff and L. T. Kroczek-Lab, Introduction into Flow Cytometry, Berlin: Robert Koch Institute, 2010.

[24] R. L. Puspitasari, A. Boediono and F. Sandra, "Conditioned medium dari kultur primer sel 
syaraf Mus musculus," in Seminar Nasional X Pendidikan Biologi FKIP UNS, Solo, 2013.

[25] D. Agustina, "Potensi Leukemia Inhibitor Factor dalam peningkatan kemampuan conditioned medium untuk pengarahan Embryonic Stem Cells mencit menjadi cardiomyocyte," Institut Pertanian Bogor, Bogor, 2009.

[26] D. Budhiarko, "Kemampuan Conditioned Medium Dari Kultur Primer Pankreas Dewasa
Dalam Mengarahkan (Diferensiasi) Embryonic Stem Cell Mencit Menjadi Sel Beta Pankreas," Institut Pertanian Bogor, Bogor, 2010.

[27] S. Wibowo, "Modul Pelatihan SPSS: Aplikasi Pada Penelitian Sosial," Fakultas Psikologi, Universitas Muhamadiyah Lampung, Lampung, 2010. 